Doyle, G. (2014) Film support and the challenge of 'sustainability': on wing design, wax and feathers, and bolts from the blue. Journal of British Cinema and Television, 11 (2-3). pp. 129-151. ISSN 1743-4521

Copyright @ 2014 Journal of British Cinema and Television

A copy can be downloaded for personal non-commercial research or study, without prior permission or charge

Content must not be changed in any way or reproduced in any format or medium without the formal permission of the copyright holder(s)

When referring to this work, full bibliographic details must be given

http://eprints.gla.ac.uk/95083

Deposited on: 02 December 2014

Enlighten - Research publications by members of the University of Glasgow http://eprints.gla.ac.uk 
Final Author Version

Forthcoming (2014) in Journal of British Cinema and Television, 11 (2-3): 129-151.

\title{
Film support and the challenge of 'sustainability': On wing design, wax and feathers and bolts from the blue
}

\section{Gillian Doyle}

Author's contact details:

Professor Gillian Doyle

Director, Centre for Cultural Policy Research

University of Glasgow

9 University Avenue

Glasgow

G12 8QQ

Telephone: 0141330 3806; Fax: 0141330 4142; Email: Gillian.Doyle@Glasgow.ac.uk

\begin{abstract}
In recognition of the importance of film in generating both economic and cultural value, the UK Labour Government set up a new agency - the UKFC - in 2000 with a remit to build a sustainable film industry. But, reflecting a plethora of differing expectations in relation to the purposes behind public support for film, the UKFC's agenda shifted and broadened over the organisation's lifetime (2000-2011). Apparently unconvinced by the UKFC's achievements, the coalition Government which came to power in May 2010 announced the Council's abolition and reassigned its responsibilities as part of a general cost-cutting strategy. Based on original empirical research, this paper examines how the UKFC's sense of strategic direction was determined, how and why the balance of objectives it pursued changed over time and what these shifts tell us about the nature of film policy and the challenges facing bodies that are charged with enacting it in the $21^{\text {st }}$ century.
\end{abstract}

\section{Key words}

UK film policy; film support bodies; UK Film Council; film industry; sustainability; recoupment; funding priorities. 


\section{Film support and the challenge of 'sustainability': On wing design, wax and feathers and bolts from the blue}

\section{Introduction}

In many countries including the UK, the importance of film in generating both economic and cultural value is reflected in special policies to support the sector (Herold, 2010). The imperatives that drive film policy are varied (Hill, 2004) but typically they centre on widening audience access to locallymade and promoting the competitive position of local producers in an industry that, in Europe and beyond, is generally heavily dominated by the Hollywood-based 'majors'. The impetus to support film has resulted in the formation of a variety of models of intervention and of agencies dedicated to implementing film policies. But, reflecting the differing and sometimes competing policy priorities that are an inherent aspect of cultural industries, film support bodies are often faced with a complex set of imperatives. Prevailing models of support are prone to criticism if perceived as placing too much emphasis on commercial as opposed to cultural aims, or vice versa (Mansfield, 2009). At the same time, digitisation and growth of the internet have raised new challenges for traditional systems of public support for film in the $21^{\text {st }}$ century (O'Regan and Goldsmith, 2006).

This article examines the history and efficacy of the UK Film Council (UKFC), an agency which was established in April 2000 and, for over a decade, was the main body responsible for supporting the film industry and film culture in Britain. Set up by the New Labour Government (1997-2010) with a remit to build a 'sustainable' film industry, the Council's agenda shifted and broadened over its lifetime. While the model of support it offered ensured the funding of a wide range of films and was viewed by some as effective, the more ambitious aims with which the UKFC was originally charged - of making the UK film production sector sustainable and of securing a global position in distribution - were not achieved. After only a few months of coming to power in May 2010, the new coalition Government announced a general cost-cutting strategy, part of which was the abolition of the UKFC and a reassignment of its responsibilities, mainly to the British Film Institute (BFI).

The rise and fall of the UKFC and transfer of its activities to the BFI raise fundamental questions both about the role of film support bodies in delivering strategic support for the sector and about how, in the $21^{\text {st }}$ century, interventions for film need to be framed and put into operation. A number of earlier studies consider the history of film and film policy in the UK (Dickinson and Street, 1985; Hill, 1996, 2004; Murphy, 2009; Street, 2009). Nowell-Smith and Dupin (2012) provide an extensive history of the BFI - one of the UK's oldest cultural institutions and the predominant support body for film prior to the arrival of the UKFC - from 1933-2000. Some earlier work has focused specifically on the efficacy of film support during the more recent period when the UKFC was in operation (Dickinson and Harvey, 2005; Hill, 2012; Magor and Schlesinger, 2009; Perkins, 2012; Wayne, 2006; Street, 2012). This article adds to this earlier work by utilizing the case study of the UKFC to probe how film policy is interpreted, developed and re-shaped institutionally by the public support bodies which are charged with enacting it. 
Drawing on original empirical research carried out as part of an extensive AHRC-funded study ${ }^{1}$ this article examines how and why the objectives pursued by the Council changed over time and how, through shifting political and market circumstances, the organization negotiated a range of competing economic and cultural objectives. As the key strategic support body for film from 2000-2011, the UKFC provides a good case study for investigating the changing pressures on models of public support for film in the $21^{\text {st }}$ century. The findings presented here derive from a series of interviews conducted with key industry stakeholders and former senior personnel and Board Members of the UKFC. The time-frame covers a period of significant political and technological change, enabling analysis of how these key factors have shaped policy design and implementation. As well as tracing how the Council's sense of mission evolved over its lifetime, this article also presents some preliminary reflections on the nature of the challenges faced by public support bodies for film in the 21 st century and what strategic lessons may be drawn from the UKFC's overall experience.

\section{Sustainability - the original remit}

In the period of the late 1990s which immediately preceded the birth of the Council, discussion of film policy in the UK frequently centered around concerns about the dominance of Hollywood and the comparative weakness of indigenous production (Middleton, 1996). Although it was widely recognized that the vertically disaggregated structure and small scale of operations of UK film companies placed the British production sector at a disadvantage, little consensus existed about how these issues might be addressed (Pratten and Deakin, 1999). The establishment of a National Lottery in the mid-1990s meant that additional funds had become available to support film. But responsibility for awarding these funds was initially vested with the Arts Councils of England, Wales, Scotland and Northern Ireland and, fuelled by a critical press, the predominant perception was one of general under-performance on the part of lottery subsidized films (Hill, 2012: 336).

It was time for a change in approach and the election of the New Labour Government in 1997 quickly brought that change. At his first budget in 1997, Chancellor Gordon Brown reintroduced tax reliefs for films produced in Britain with budgets of under $£ 15 \mathrm{~m}$. Chris Smith, the incoming Secretary of State for Culture Media and Sport, announced the establishment of a Film Policy Review Group (FPRG) to consider and report on UK film policy (Dickinson and Harvey, 2005: 420; Pratten and Deakin, 1999: 43). Chaired by Film Minister Tom Clarke ${ }^{2}$ and Stewart Till, president of Polygram Filmed Entertainment International, the FPRG set out its findings in A Bigger Picture published in 1998 (FPRG, 1998). This Report, whose main recommendations included the introduction of a voluntary industry-wide levy to support British production, highlighted the need to foster an industry that was more commercially self-sustaining (ibid: 4; 13). A small clause towards the end of the Report heralded what was to become the most significant outcome (ibid: 50) - the creation of a single new support organization for film to take over the work of bodies including the Arts Council, British Screen Finance and the British Film Commission. The idea of establishing a unified strategic body for film predated the FPRG, as explained by John Woodward ${ }^{3}$ (later to

\footnotetext{
${ }^{1}$ This is an Arts and Humanities Research Council-funded project (AH/J00457X/1) entitled 'The UK Film Council: A Case Study of Film Policy in Transition' which runs from Oct 2012-Sept 2014. Principal Investigator: Gillian Doyle; Co-Investigators: Philip Schlesinger and Raymond Boyle; Research Associate: Lisa Kelly.

${ }^{2}$ Interviewed by the author on March 8, 2013.

${ }^{3}$ Interviewed by the author and Philip Schlesinger on February 13 (2013a) and by author on April 4 (2013b).
} 
become Chief Executive Officer of the Film Council) who while Chief Executive of the UK trade association for producers PACT in 1996/97 had been asked by the Secretary of State to advise on this as a possibility:

Chris [Smith] said to me, what do you think about all these different bodies...? Wouldn't it make more sense to pool all the stuff together? ...Could you write me a paper about how you might rationalise it all? Which I did. .. It was a model for one overarching film organisation for the industry... [W] hen the FPRG Report was published, there was a page at the back which basically, literally in the small print, said, by the way, we are going to 'rationalise the machinery...

(Woodward, 2013a)

The creation of a new funding body offered a means through which the broad aim espoused in the 1998 Report - 'to create a self-sustaining commercial film industry' (FPRG, 1998: 4)- could be put into operation. The replacement of numerous film agencies with a single new body also promised to make oversight of a sector characterized by multiple constituencies of interest more straightforward. A key issue surrounding the establishment of a new body with responsibilities straddling both industrial and cultural aspects of film policy was how to integrate the British Film Institute (BFI). The BFI which was awarded a Royal Charter in 1983, had been the main support body for British film for many decades and was historically well regarded as a cultural institution. But the BFI was struggling with management and funding problems in the late 1990s (Nowell-Smith and Dupin, 2012) and it was hoped that the appointment of the commercially experienced and successful film director Alan Parker as Chairman and of John Woodward from PACT as CEO could help resolve these.

Woodward recollects that he and his Chairman were summoned from the BFI to Chris Smith's office one day and told that he wanted to act on the recommendation to create a unified film body. Discussions about the shape of the new body and the role of the BFI 'went back and forth' and in the end it was decided that the BFI should retain responsibility for cultural aspects of film support but overseen by the newly established Film Council which would provide its annual grant-in-aid thus relegating the BFI to the status of a second tier body:

... I think that Chris was quite keen ... to get away from this kind of situation where everyone would turn up from these different organisations each year and lobby for their bit of the pie... [T] here had to be a better and a more coherent and objective way to look at what the priorities were. Undertaken by an expert body [with an understanding of the complexities of the film industry] was going to be far better than by the Secretary of State and three civil servants ...

(Woodward, 2013a)

The Film Council commenced operations in April 2000 and, as with Ofcom set up shortly afterwards in 2003, represented what one policy adviser ${ }^{4}$ called 'an iconic New Labour creation' whereby an array of industry bodies were replaced by a single entity intended to bring greater strategic coherence and efficiency. But the creation of a single support body did little to ameliorate the inherently complex and multi-faceted nature of the policy aspirations surrounding film support. The Film Council made it clear that its primary mission would be to promote industry sustainability while the cultural remit was generally devolved to the BFI (Film Council, 2000). However, tension between these differing aspects of the rationale for public support of film was inscribed from the

${ }^{4}$ Interviewee 14, Advisor to UKFC - Interviewed by project team on May 5, 2013. 
outset within the institutional architecture of the Film Council and was 'epitomised or symbolized by the awkward and very difficult relationship between the BFI and UKFC' which was to remain as 'a fault line' throughout the life of the UKFC (interviewee 14, 2013).

The idea of prioritising commercial sustainability had been set by the FPRG but was fully supported by Chris Smith, according to Stewart Till ${ }^{5}$ who chaired the Review Group and subsequently joined the Board of the Council. For Till, the initial focus on sustainability reflected and was a response to the preceding period when allocation of support for production had been conducted with little or no positive commercial outturns and many lottery-funded films failed to achieve any form of distribution. According to Woodward, it was essential that the new body should 'turn around' perceptions as otherwise there was a risk lottery funding for film might be discontinued. For Till, adopting sustainability as the goal was not so much about literally trying to wean UK independent producers off public subsidies as establishing 'the right sort of aspiration' or the general sense of direction for film support policies. Nonetheless, the focus on building a sustainable industry was in some respects a burden for the new body as Woodward explains:

It was Chris Smith who hung ['sustainability'] around our neck. Nobody at the Film Council wanted that I have to say... It's a very unhelpful word. It's a word that lacks any kind of clarity... Where I come from 'sustainable' would mean that you make some sort of investment in the film industry but in the end it ceases to need public money in order to support itself... That was what people immediately thought the end-game was. So you terrify everyone because they can't see any pathway to that... There's no historical precedent for film industries that are self-sustaining without public subsidy and support and policy. And people got very scared. And then that ghost gets pushed back on the organization because you're there saying 'so how are you going to do this then?'

(Woodward, 2013a)

\section{From 'sustainability' to an internationally 'competitive' industry}

The agenda for the initial phase of the Council's life (2001-2003) was set out in a strategic policy statement (Film Council, 2000) which confirmed that, while that the cultural role of the organization was 'largely delegated to the BFI and its regional partners', the Film Council would take in hand the industrial remit. A two-stage plan of action focused on, first, using 'public money to make better, more popular and more profitable films in real partnership with the private sector' and, second, over the longer-term creating 'change within the industry at a structural level in order to create a truly durable sector' (ibid: 1 ).

Unlike the film funding bodies it replaced, the Council was not burdened by any historical legacy in relation to how it should use its funds and so, notwithstanding the broad sustainability remit, the new organisation enjoyed a level of freedom and independence in interpreting its mission and in defining its own course which was quite exceptional. As one of the initial members of the Council's Board ${ }^{6}$ put it, 'given a kind of carte blanche' to decide what it wanted to do with Lottery funds (subject to the Lottery rules). But the Board was composed of individuals whose viewpoints and sectoral affiliations differed, some of whom wanted to encourage more alliances between British producers 
and Hollywood studios and 'would have almost put all the production money into big budget stuff' and others of whom were more inclined to protect cultural film-making (Interviewee 4, 2013). Nonetheless, the Board played a key role in shaping the organisation's funding priorities as explained by Alan Parker ${ }^{7}$ its first chair:

The one significant thing I did was to help with its creation and that part of it was not easy because the industry is made up of a lot of disparate groups... who are always at each other's throats... The great strength of the Film Council was the fact that particularly the first Board was made up of cutting edge professional film-makers, producers, directors, distributors...It was a single body responsible for every single aspect of film... The stature of [people on the first Board] was really significant and people listened.

$[T]$ he fundamental thing we decided was... how we allocated funds... We came to the conclusion that three funds and not just one were necessary: First, the Premiere Fund, which was meant to make commercial films that made a profit. Second, the... New Cinema Fund was for cutting edge films which were not expected to make a profit but actually were meant to encourage film-makers who didn't really fit into the normal commercial bag. And then the third and most important thing ... the Development Fund which was to develop screen plays.

(Parker, 2013)

The creation of the Premiere and Development Funds signaled a marked shift in the emphasis of film support towards fostering a more business-minded and market-led approach to new production. These initiatives responded to the prognosis in the FPRG Report that the sector was too productionled and fragmented (Pratten and Deakin, 1999). At the same time, the establishment of a New Cinema Fund whose purpose was to back radical and innovative film-making showed that the new body was also committed to the wider and more culturally-based remit surrounding public support for film.

As Chair of the Council, Parker played a significant role in guiding the organisation through its first phase and a speech entitled Building a Sustainable UK Film Industry delivered to an audience of film executives in November 2002 became an important landmark. Parker praised the UK industry's 'world-class filmmaking talents' and argued for more skills development and investment in infrastructure and facilities. But the main thrust of his speech was that the industry needed to reinvent itself and 'abandon forever the "little England" vision of a UK industry comprised of small British film companies delivering parochial British films' (Parker, 2002: 8) and instead adopt a more demand-led distribution-focused approach that would enable UK films to compete more effectively in the global marketplace. Parker also called for tax incentives to encourage greater inward investment in UK film production.

The call to focus public support more on distribution and inward investment rather than just investing in production caused alarm in some quarters. But, as Parker points out, the film industry is made up of different areas:

We've had two industries from the very beginning and it's not a bad thing... You have inward investment which relies upon our tax incentives to encourage films, mostly from the United States - very large budget films that fill our studios, and most importantly, create an incredibly qualified workforce of technicians who then can feed into, though not at the same rate of pay, 
but can feed into the indigenous industry. And you have the indigenous industry which is the one that cannot survive - not just in the United Kingdom, nowhere in Europe can it survive without government subsidy of some kind.

(Parker, 2013)

Others on the Board of the Film Council shared the view that support ought to be focused on encouraging a more distribution-led approach and, in evidence to a Parliamentary Committee concerned with film policy in September 2003, the organisation's CEO John Woodward pleaded with the Committee saying: 'for God's sake let us make sure that production is properly harnessed to distribution' (HC, 2003: 30). Evidence to that same Committee from successful UK film company Working Title, a subsidiary of Universal, reinforced the argument that distribution is vital to the prospects of the UK film sector:

'We believe that if you are going to be competitive in the motion picture business, not only within your own market but within a worldwide context, there is one thing that you have to tap and that is distribution. The distribution business, like many other businesses, for the film business is run out of America by the majors and that has been the case for the last 50 or 60 years. If you cannot harness that distribution, then you do not really stand a chance'

(HC, 2003: 21)

However not everyone agreed with the diagnosis that 'the idea of building a stable of rights-owning film production companies is a fantasy' (Parker, 2002: 9) and that, instead, promoting a more distribution-led approach was the right way forward for UK film policy. According to Peter Watson $^{8}$ of Hanway Films:

John Woodward and Alan Parker came up with this whole concept of distribution-driven industrial development which became sort of like an article of faith.. That set them off on the wrong course from the very beginning... Alan Parker despised the whole culture of filmmakers being supported by the state ... and believed the only thing would be to operate as a commercial film-maker.. He helped make the UKFC face away from Europe where so many of our film-makers had developed long-standing relationships and a support network.. and told everyone that the only way for us to compete was to follow the studio model. But without any real understanding of what it involved to be a studio which is a globally integrated distribution entity with billions of dollars of capitalization.

(Watson, 2013)

Another prominent film-maker ${ }^{9}$ agrees that the direction taken by the Film Council was ideologically ill-founded and betrayed a lack of sympathy towards the cultural aspects of supporting film:

[I]n my view [Parker's speech] was completely wrong headed... He and John Woodward got it completely wrong...And many of the initiatives that were taken thereafter were trying to follow through on that policy and it was all going in the wrong direction...

[There was] a sort of a prejudice against producers and the production companies... He said 'I think it's time everybody realised that production companies can never make viable businesses.' Now there were a lot of quite viable production companies sitting in the audience thinking 'hang on a minute' ... a lot of people were appalled.

(Interviewee 9, 2013)

${ }^{8}$ Interviewed by the author on March 11, 2013.

• Interviewee 9, Independent film producer - Interviewed by the author on March 12, 2013. 
The designation of independent production as inherently an uncommercial activity was regarded by some producers not only as inaccurate but also, in practical terms, as unhelpful to the image of a sector that, as the Middleton Report (1996) had confirmed, already suffered from a range of difficulties that impeded its efforts to attract private sector investment. Moreover, the idea that interventions should be targeted at the most commercially promising aspects of the film industry rather than at creation of film content, where prospects were comparatively poor, raised fundamental questions about the rationale and purpose underlying public support for film:

...[W]hat is the point of an intervention in the film industry if it's not the making of the films?

... Actually when it really comes down to it, it has to be seen, in part, as a cultural intervention, otherwise why are we bothering? There are other industries that you could subsidise with less money and that would probably employ more people. We don't employ that many people. It's quite expensive. So actually, why are we doing it? [I]t is ... economic ... but it's also a cultural issue..

(Interviewee 9, 2013)

The development of a sustainable and distribution-led industry remained a central objective in the Council's next strategic plan (UKFC, 2004). Publication coincided with the appointment of Stewart Till, until then deputy Chair, to replace Alan Parker as Chairman of the Board and it followed on from a consultation conducted by the organisation which suggested its first three year plan was viewed as being 'overwhelmingly successful' (UKFC, 2004: 5). But, for the second phase of the Council's existence (2004-2007), the funding and policy priorities began to widen and a hint of this was to be found in the organisation's change of title from Film Council to 'UK Film Council'. John Woodward explains that Phase 2 was when the Council was able to move beyond remedying the earlier systems of lottery support for film and adopt:

a more sophisticated structure to pump-prime the parts of the industry where we thought relatively small amounts of money could make a big difference, training and skills being an obvious one, regional development and activity being another obvious one...

(Woodward 2013a)

A key event that was to re-define the Council's sense of mission during this phase was the decision by the Government to reform fiscal incentives for film. The (Sections 42 and 48) tax relief measures introduced back in 1997 to encourage more investment in production had been warmly welcomed by industry and extended twice in the 1998 and 2001 budgets (Magor and Schlesinger, 2009: 12). But manipulation and abuse of the schemes was widespread and the cost of providing these reliefs was high - in the order of $£ 600-700$ m per year. According to one industry advisor, 'what went on in 2003-2004 was nothing short of a scandal' (interviewee 14, 2013). Critics also noted that, amongst legitimate film investors, the prime beneficiaries of generous UK tax relief schemes were the major US studios.

In 2004, the Treasury announced that loopholes in the existing tax arrangements for film would be closed off and that it would seek approval from the European Commission for a new and more effective form of tax break aimed at film producers. The news that existing reliefs were to be removed caused dismay amongst film investors and prompted Michael Kuhn of Qwerty Films in a speech to PACT in May 2005 to criticize the Council for failing to foresee and failing to adequately defend the interests of the film industry against this unwelcome shift in policy:

'To many of us it seems that this Janus-like body, representing us to the government but not representing us; representing government to the industry but helpless in light of, and 
blindsided by, recent tax changes, not hearing criticism, is in need of reform itself.'

(Kuhn, cited in Gibson, 2005)

The controversy surrounding a potential withdrawal from tax breaks for film had a decisive influence over how the UKFC articulated its primary role and sense of allegiance from this stage onwards. Tax reliefs were an issue where many people, including some members of the Film Council's board, felt that the organisation should 'stand up to Government' (interviewee 14, 2013). However, as a letter from Woodward responding to Kuhn's speech which was leaked to the trade press in July 2005 revealed, although the Council's vision for 'a more sustainable industry' included support from more efficiently designed tax breaks, the organization had no intention of defending the discredited existing arrangements and was 'never going to be privy to private scams perpetrated between accountants, tax funds and producers' (Woodward, cited in Macnab, 2005). A tension existed between those who thought the UKFC should be 'hand-maiden of industry' versus others 'who understood that quite properly we were an organization operating in the public interests, funded by government' (interviewee 14, 2013). This prompted John Woodward to clarify in a conference speech in 2005 that, rather than existing primarily to promote the interests and commercial strength of the film industry, the Council's main purpose was to serve the wider public interest:

'We sit between government and industry but we are not an industry body. We are a government body...Our job is to give the government impartial advice about what is sensible... and to try and mediate between the aspirations and ambitions of a rapacious film industry and what is achievable and realistic.'

(Woodward, cited in Macnab, 2010)

Although withdrawal of Section 42 and 48 tax reliefs precipitated some criticism of the UKFC, the organisation's work with Treasury to negotiate the introduction of suitable alternatives is regarded by many as one of the Council's most significant achievements. A new scheme of Film Tax Credits for qualifying UK films under $£ 20 \mathrm{~m}$ was introduced through the Film Act 2006, thus ensuring continuity in this broad form of support. Film historian Professor John Hill ${ }^{10}$ who was a member of the first Board suggests 'the fact that the Treasury were persuaded to carry on with tax credits ... has a lot to do with the work of John Woodward, Alan Parker and Stewart Till'. Former Secretary of State for Culture, Media and Sport James Purnell ${ }^{11}$ takes the view that 'getting tax breaks sorted out' was the area where the UKFC was at its strongest.

This dispute was symptomatic of challenges the Council faced in managing its relationship with industry which stemmed not only from the persistence of assumptions that advancing the commercial interests of industry should be its raison d'etre but, in addition, from the fact that 'industry' was and is comprised of a number of different sectors and constituencies whose interests were not identical. According to an advisor to the UKFC, many in the distribution and exhibition sectors felt that that UKFC was too 'supplier led' and concerned with the interests of producers (interviewee 14, 2013). But the latter is not a single unified constituency and so, even were the Council's efforts confined to supporting production, it still faced a complex array of competing pressures in relation to how best to direct its support. For example, whereas some producers were

${ }^{10}$ Interviewed by the author on March 6, 2013.

"Interviewed by the author on May 22, 2013. 
calling for tax breaks to be framed in such a way that cultural stipulations would not deter inward investment, others were less convinced about the merits of directing public support towards major international players and wanted to see more emphasis on support for bone fide British film-makers (Dickinson and Harvey, 2005; Wayne, 2006).

A particular area of concern for independent producers was the recoupment terms surrounding grants awarded by the Film Council. Many complained that, although part of a publicly funded organization, the Business Affairs Department of the UKFC behaved as though it was a commercial studio, setting itself high targets for rates of return from lottery-funded films that made a profit and refusing to allow producers any share in the Council's recoupments. According to one independent producer:

[A]ll the terminology they used... and the way they comported themselves was more like studio executives than people who were there with a public service ethos... They were extremely tough with producers on terms of trade... They demanded aggressive positions when it came to credits on films... They fought producers tooth and nail to get the best recoupment position for their money... In squeezing the producer that way they weakened the producer... They were obsessed about the recoupment targets.

(Watson, 2013)

John McVay ${ }^{12}$ Chief Executive of PACT, also takes a critical view of the emphasis placed by the UKFC on emulating the market-oriented distribution-led approach of the US major studios. At the outset, PACT had been hopeful that the Film Council would 'look at financing indigenous films on preferential terms to allow producers to get corridors in their revenues from the movies to make them more sustainable' (McVay, 2013). But the Council was emphatic about retaining its own returns from lottery-funded films. For McVay, this stance contradicted the espoused mission of improving the financial viability of the UK industry. From the Council's perspective however, as a body dispensing public funds it was obliged and expected to carefully manage returns from any successful films it invested in so that additional funds could be recycled into new projects:

People who run profit making companies and get subsidy to invest in what are potentially profit-making entities, if their activities then start to generate revenue, it seems not unreasonable for the public purse to get that money back so it can reinvest it in other activities.

(Woodward, 2013b)

The approach taken towards support for independent producers changed in the final couple of years of the UKFC's existence. Phase 3 of the Council's life (2007-2010) was characterized by a further widening in the interpretation of its role and responsibilities part of which involved some relaxation in recoupment targets. By the time of publication of the strategic plan for Phase 3 references to fostering a 'sustainable' industry had been dropped from the rhetoric and instead this document spoke of developing an internationally 'competitive' industry built on skills and creativity (UKFC, 2007). The range of priorities addressed suggested that the Council was progressively broadening its mandate and embracing a growing set of economic and industry imperatives, greater responsibility for cultural aspects of the film remit, as well as a more sustained focus on digital technology.

\footnotetext{
${ }^{12}$ Interviewed by the author on March 12, 2013.
} 
In 2009 , the introduction of a 30 percent corridor for producers on recoupment was announced - i.e. a $30 \%$ proportion of profits recouped by the Council from lottery-funded film projects which were successful would now go to producers rather than all being recycled back into the UKFC's budget. To some extent this softening in the Council's position reflected a broader process of evolutionary change in the organization's agenda as over time it negotiated and sought to accommodate an everwider array of pressures and concerns from across the film industry and beyond. But another factor that re-shaped the Council's priorities over time was changes in the profile of its Board of Directors.

Evidence from a range of interviewees confirms that the means by which the Council's sense of direction was determined and recalibrated over time was largely through an ongoing process of dialogue and negotiation between, on one hand, the organisation's executive management - of which John Woodward was unquestionably the key figure - and, on the other hand, its Board. As is typical of arrangements for monitoring of quangos (quasi-autonomous non-governmental organisations) or arm's length bodies in the UK, the Council was overseen by a Board appointed by Government (in this case DCMS) in accordance with Nolan principles. ${ }^{13}$ The Board of fifteen members met monthly to discuss and provide strategic oversight of the activities of the UKFC. It served both as a source of new ideas about the interventions and policy direction that the Council should take and as the body that moderated ideas emanating from within the organization.

While monthly meetings provided a forum for open discussion of strategy, former participants agree that the individuals who wielded greatest influence over decision-making were the Chairmen of the Board and the organisation's CEO. A wide consensus exists that John Woodward was an effective CEO. But his energetic and decisive style of leadership was unpopular with a few critics in the independent production community who question whether the extent to which he personally shaped the Council's agenda and held sway over the strategic and operational direction of the organization was excessive. However, in a contrary vein, many former members of the Board share the conviction that it was they - the Board - rather than the CEO who were primarily responsible for directing the policy and (at a strategic level) the activities of the UKFC.

Evidence of the influence of successive Chairmen, all of whom were film-makers and executives of exceptional international stature, can be discerned through changes in the central focus of the Council's mission from initially promoting commercial sustainability and a distribution-led approach towards eventually more support for independent production and innovation. Whereas the background of the first Chairman, Alan Parker (1999-2004), involved working closely with the major US studios in creating a number of globally acclaimed and popular films and, likewise, the second Chairman Stewart Till (2004-2009) had worked as a senior executive within international distribution, the next and final Chairman of the UKFC, Tim Bevan (2009-2011) had started life as an independent producer and was seen by many as a champion of the creative community.

A final strategic plan covering the period from 2010-2013 and the need 'to help ensure a successful transition into the digital age for UK film' (UKFC, 2010:8). Whereas back in the early days of the Film Council, digital technology received little attention - it was not mentioned, for example, in Alan Parker's landmark speech in November 2002 - the 2010 strategic plan marked a decisive re-

${ }^{13}$ A set of ethical guidelines for those in public office named after the first Chairman (Lord Nolan) of the Committee on Standards in Public Life. 
weighting of priorities, as former Chairman Tim Bevan ${ }^{14}$ explains:

When the Film Council was set up.. the internet was young at that point. But by 2009 it [was having an impact] and so I felt when I took over ... the whole Film Council needed to have a re-evaluation - a look at what its function was and how it sat within the media landscape at that point. ...I felt ... putting public money into film production should really be directed as much as possible at first and second time film-makers...

We also felt... what needed looking at was how the new world of [digital] distribution was ... going to affect the film industry. ..[ We wanted to set up] an 'Innovation Fund' where people working in areas [related to new technologies] that would have substantial impact on our industry ... could apply for funding to support that. Now that never actually came to fruition, that fund, because by the time we had just elected to proceed with it, we got shut down!

(Bevan, 2013)

Thus, at the end of a long evolutionary path and just as the UKFC had freshly taken stock and was about to proceed with what many regarded as a better-informed, more fully rounded and a realistic appreciation of the priorities that a support body for film ought to be pursuing in the $21^{\text {st }}$ century, the election of a new Conservative-led coalition government in May 2010 precipitated an announcement in July, described by Bevan as 'a complete bolt from the blue', that as part of a cost-cutting exercise, the organization would be closed down forthwith and responsibility for its activities transferred to another body.

\section{Flying too close to the sun?}

Prominent amongst those who spoke out against the closure of the UKFC, acclaimed film-maker David Puttnam (2010) argued that, whereas film policy in Britain had for many decades been characterized by 'lack any real strategic coherence', the creation of the Council in 2000 had at last tackled this problem. Whereas previously policies to support film had involved a variety of differing government ministries and agencies, the creation of the Film Council introduced a single unified body whose remit encompassed distribution, exhibition and production of film and a body which, characterized by high levels of sector-specific expertise, was well placed to advise government on all aspects of film.

A concentration of industry expertise and of funding within the Film Council enabled the organization to move forward decisively with enacting a cohesive set of objectives. But being a unified body involved drawbacks too. For Woodward, being charged with overall responsibility for all aspects of film support meant that, inevitably, the organization was fallible to image problems and criticism from those who regarded it as too centralized and controlling:

[T]he strength of the Film Council came through the fact it was unified and all of the power and influence and money ... all that brain power was in one place. That made it very, very strong. The flip side of that relates to the stakeholders themselves. That can make the organisation look very monolithic and it also means that, regardless of how many funds you have and how you disperse the money into executive agencies or different departments, the organisation is seen as a 'one stop shop' and that... works against you.

(Woodward, 2013b)

\footnotetext{
${ }^{14}$ Interviewed by the author on April 29, 2013.
} 
Certainly, independent film-makers who were dissatisfied with the strategic approach adopted by the UKFC also tended to be critical about excessive centralization of power within the organisation, arrogance on the part of its senior executives and too much 'spin'. As one interviewee put it, the Film Council was 'an organization drowning in hubris' (Watson, 2013). The extent to which the Council devoted itself to sustaining positive publicity about its strategic approach and performance was reflected even in the layout of its premises:

If you looked at the physical geography of Little Portland Street where they had their HQ, John Woodward's office ... was flanked on the one side by the press office and on the other side the statistics office... And they were his two most important instruments of spin...

(Watson, 2013)

A consultant who worked for the Film Council conceded that there is some validity to criticisms that the organization sometimes focused excessively on 'spinning of the evidence' (interviewee 14, 2013). On the other hand, all publicly-funded bodies are under pressure to demonstrate to their political paymasters and the wider public the ways in which they are successfully fulfilling their remit and providing value for money (Knell and Taylor, 2010). The Arts Council of England, which is similarly required to justify the way in which it uses public funds to support the arts, regularly commissions impact studies and reports that confirm the value of its interventions.

High salaries for senior executives was another area of perceived excess. Concerns had been triggered right from the start when, in 2000, the inaugural head of the Premiere Fund was appointed at a salary of some $£ 180,000$ per annum. The Council justified high payments on the basis that, to attract talented professional film executives, it needed to pay something approaching market rates. Woodward points out that the UKFC was 'utterly transparent' about salaries and expenses and since appropriate procedures were followed for oversight by 'DCMS, who approved all the senior salary packages through to the Board Directors who looked after the annual budget... [there was] nothing to be ashamed about' (Woodward, 2013b). Even so, in the words of one industry expert, high salaries created the wrong perception amongst independent producers who often have to live a 'hand to mouth' existence (interviewee 14, 2013). Only towards the end of the Council's life were steps beginning to be taken to address levels of executive pay. By this stage, the perception had taken hold of an organization in which top personnel were overpaid - a pattern commonly to be found amongst quangos and which contributed to a view that, as a class, these organisations lacked appropriate governance and were a suitable target for government cost-cutting campaigns (Gash and Rutter, 2011).

Despite being confronted by challenges that, arguably, any 'monolithic' organization might be expected to face in managing its image and its relationships across a somewhat disparate range of stakeholders, the UKFC was effective in putting into action a number of the strategic priorities it set out over the course of its lifetime. A full evaluation of the Council's performance is beyond the aims of this article. Nonetheless, notable changes include a substantial increase in levels of regional dispersion of film funds and in investment in skills development during the 2000-2010 period as compared with earlier decades. Audience levels increased somewhat during the UKFC's tenure as lead support body for film and inward investment in film production in the UK grew significantly (Perkins, 2012: 315). In 2010 alone investment in UK production by foreign studios amounted to over £1bn (FPRP, 2012: 2). 
In addition, the Film Council is credited with bringing unprecedented levels of expertise and commercial acumen to processes of awarding funds for film production. According to one senior executive at a partner agency, ${ }^{15}$ 'what the Film Council absolutely did, without a shadow of a doubt, was that they professionalised us as a nation in the way that we approached film production'. As a lasting tribute to its achievements in this respect, one of the films the Council awarded lottery funding to shortly before being closed down - The King's Speech - as well as winning four Oscars became the highest grossing independent British film of all time in 2011 (FPRP, 2012: 5).

But the original objective of creating a commercially 'sustainable' industry was never achieved. Despite over a decade of interventions by the Council, the British film industry is still fragmented and predominantly consists of small and under-capitalised firms. The share of the UK box office accounted for by British independent films was on a slight upward trend during UKFC's tenure but it still averaged only 5.5\% in 2001-2010 period (ibid: 3; 11). Amongst those UK-made independent films that achieved theatrical distribution during this time, many were strongly dependent on public funding (ibid: 46).

Commercial sustainability provided a strong initial sense of direction for the Council but ultimately proved to be an unattainable target. However, it is questionable whether, in the context of the UK or other European countries, 'sustainability' represents a reasonable founding remit for any strategic support body for film. Since the scale of resources and the interventions needed to turn the UK into an industry capable of competing in any way seriously with Hollywood is prohibitively high, some might argue that a more culturally driven agenda for film support amounts to a better use of limited public funds. However, the aesthetic and commercial dimensions of film are not easily separated culturally worthy output is dependent on the existence of a viable production infrastructure. So a significant challenge that faced the UKFC throughout its lifetime - one that any 'unified' support body for film must face - is 'an expedient but unhelpful bifurcation of film policy and a tendency for it to be conceived as either/or: either industrial and charged with economics and sustainability, or cultural and concerned with public value and audience engagement' (Mansfield, 2009: 5).

\section{Conclusions}

The experience of the UKFC suggests some preliminary conclusions of value to other film support bodies. One is that, given the multi-faceted and complex nature of the agenda associated with promoting film, public support bodies must from the outset manage expectations carefully. On account of persistent structural and competitive disadvantages faced by the indigenous production sector in the UK and in other European countries and beyond, creating a 'commercially sustainable' production industry is not realistically within the power of any public support body for film. The fact that the Film Council was initially steered strongly towards industrial sustainability is consistent with a 'defensive instrumentalism' which some have argued is characteristic of New Labour's general approach to policies of support for culture (Belfiore, 2012). A prioritisation of economic goals for film support chimed with New Labour's broader strategy of supporting growth in 'creative industries' but failed to address the complexities surrounding excessive reliance on inward investment from Hollywood (Dickinson and Harvey, 2005). Although the UKFC eventually

${ }^{15}$ Interviewee 10, Senior Executive at partner agency - Interviewed by the author on March 27, 2013 
distanced itself from this objective in favour of a more rounded agenda, it was forever tainted by the impression that securing a sustainable industry was its primary raison d'être and a mission that, in the end, it had not managed to accomplish.

The conduct of relationships with key stakeholders is another area of challenge for film support bodies, not least because of the complexity of the film industry and the numerous differing sectors and constituencies of interest all of whom expect to be prioritized and respected (Mansfield, 2009). Friction surrounding a threatened discontinuation of tax reliefs in 2004 showed how some were critical of the UKFC for not being strongly enough on the side of industry and its commercial interests. Others however argue that the Film Council was 'in its upper echelons populated by industry people with a strong Atlanticist orientation' and the organization ought to have had stronger commitment to independent film-makers (Wayne, 2006: 63). For bodies involved in dispensing public funds, some level of disaffection, particularly amongst applicants whose funding requests have been rejected, is to be expected (Marquis and Marquis, 1995: 171). Even so, as one policy advisor who worked for the UKFC concedes, the 'style' in which relationships with independent film-makers was handled was problematic. According to Tim Cagney ${ }^{16}$ former CEO of the UKFC from 2010-2011 and now Deputy-Director of the BFI:

Definitely one of the lessons the BFI has taken on board is to constantly engage, constantly ensure that we are really listening to what people have to say... [A]t times the Film Council was probably accused... of slightly operating in a vacuum. Was that the intention of the board and the senior managers? Definitely not! But I think as things start to get much harder and more thinly spread, those questions come up.

(Cagney, 2013)

Challenges encountered by the Council in managing relations with key stakeholders were to some extent indicative of the disparate nature of its client industry. A re-weighting in the priorities it pursued over time reflected ongoing processes of negotiation between differing industrial concerns and cultural aspects of film support which were also integral to its official remit. Not only did the Council need to juggle its dual priorities, it also needed to foster good working relationships with other organisations with whom it operated in partnership to deliver its objectives. A key partner for the UKFC was the BFI which was primarily responsibility for delivering on cultural aspects of the film remit. But relationships between the two organisations were strained and at times dysfunctional (Nowell-Smith and Dupin, 2012: 304-9). Discussions about a possible merger began in 2009 but these failed to result in a concrete agreement. According to Tim Bevan who took over as Chair of the Council in 2009, the problem of poor relations between the two organisations really ought to have been tackled much earlier and more effectively in the lifetime of the UKFC. Had the Film Council managed from an early stage to integrate the BFI (which, unlike the Council, enjoyed some protection on account of its Charter status) then it is questionable whether it would so readily have fallen victim to the 'bonfire of the quangos'.

However a strong emphasis on industrial development is very much at the heart of what was distinctive about the model of support offered by the Film Council (Dickinson and Harvey, 2006: 422; Hill, 2012). For John Woodward, albeit that in 2010 there were 'still a lot of things to be done', the organisation during its lifetime had played a decisive role as a 'change agent' - the UKFC 'grabbed British film by the scruff of the neck and forced it to raise its game and

${ }^{16}$ Interviewed by the author on February 12, 2013. 
professionalise itself' according to Woodward (2013b). Whereas, as Tim Bevan (2013) argues, some of the strategic aspects of the Council's remit (e.g. its response to digital distribution technology and the level of prioritization given to independent producers) still needed further development and aspects of how the organisation operated (e.g. staffing levels and salaries) also needed correction, even the harshest critics of the UKFC tend towards the view that the organization should have been reformed rather than closed down. Woodward (2013b) observes that one the ironies surrounding the closure of the Film Council is that, having evolved and learned from its mistakes as it went along, the organisation was actually 'in pretty good shape' by 2010 . While in favour of public bodies being subjected to renewal every decade or so, he argues that the procedures for review ought to be rational and should rely on 'a clear set of objectives and some sort of evidence base about what has worked and what is needed' (Woodward, 2013a).

The abruptness of the decision to abolish the Film Council and the lack of evident and compelling grounds for so doing suggests that film policy in the UK is at times not rational. Although incoming administrations often seek to make savings by merging or closing down public bodies that are perceived as too costly or inefficient, such decisions are generally predicated on some form of analysis of the costs and benefits involved (Flinders and Skelcher, 2012). But the decision to close down the UKFC involved no prior consultation and nor was there any sign of evidence-gathering or proper analysis of the consequences, according to views gathered from an extensive range of interviewees including prominent UK film-makers, industry experts and policy analysts.

The apparently haphazard way the UKFC was terminated points inescapably to a conclusion that is not new - British film policy lacks coherence. Many industry analysts have previously drawn attention to the historically disjointed nature of interventions in this sector (Hill, 1996; Puttnam, 2010). The problem of contradictory and disjointed approaches to policies for film support is not confined to the UK (Craik, McAllister and Davis, 2003). Further confirmation of the lack of rationality underlying recent developments in UK film policy was supplied when, one month after instead of some time before the closure of the Film Council, the Government in May 2011 announced a new review of UK film policy (DCMS, 2011). Perhaps ironically, the first objective set for the Review Panel was 'to provide greater coherence and consistency in the UK film industry' (FPRP, 2012: 1). It remains to be seen what role a demonstrated indifference on the part of the Government as to the efficacy of the existing mechanisms for public support of film might play in enabling or thwarting this aim. 


\section{References:}

Belfiore, E (2012), “'Defensive instrumentalism” and the legacy of New Labour's cultural policies', Cultural Trends, 21(2): 103-111.

Craik, J. McAllister, L and Davis, G (2003), 'Paradoxes and Contradictions in Government Approaches to Contemporary Cultural Policy: An Australian Perspective' The International Journal of Cultural Policy, 9 (1): 17-33.

DCMS (2011), Film Policy Review Consultation, DCMS June 24.

Dickinson, M and Street, S (1985), Cinema and State: The Film Industry and the Government, 19271984, London: BFI.

Dickinson, M and Harvey, S (2005), Film Policy in the UK: New Labour at the movies, The Political Quarterly, 420-29.

Film Council (2000), Towards a Sustainable UK Film Industry, London: Film Council.

FPRG, Film Policy Review Group (1998), A Bigger Picture, London: TSO.

FPRP, Film Policy Review Panel (2012) A Future For British Film: It begins with the audience, London: DCMS.

Flinders, M and Skelcher, C (2012) 'Shrinking the quango state: five challenges in reforming quangos', Public Money and Management, 32 (5): 327-334.

Gash, T and Rutter, J (2011), 'The quango conundrum', The Political Quarterly, 82(1): 95-101.

Gibson, O (2005), 'Cinema levy call to save film industry', Guardian, May 10. Retrieved at:

http://www.guardian.co.uk/uk/2005/may/10/film.media

HC, House of Commons (2003), The British Film Industry, Report of the Culture Media and Sport Committee, Sixth Report of Session 2002-03, HC 667-1, London: HMSO.

Herold, A (2010), European Film Policies in EU and International Law; Culture and Trade Marriage or Misalliance? Groningen: Europa Law Publishing.

Hill, J (1996), 'British Film Policy' in Moran, A (Ed), Film Policy, London: Routledge, pp101-113

Hill, J (2004) 'UK Film Policy, Cultural Capital and Social Exclusion', Cultural Trends, 13(2): pp $29-40$.

Hill, J (2012), 'This is for the Batmans as well as the Vera Drakes': Economics, Culture and UK Government Film Production Policy in the 2000s, Journal of British Cinema and Television, 9: 333356.

Knell, J and Taylor, M (2011) Arts Funding, Austerity and the Big Society: Remaking the case for the arts, RSA.

Macnab, G (2005), UK Film boss responds to 'unrealistic' Kuhn speech, Screen Daily, 28 July. Macnab, G (2010), The life and death of the UK Film Council, Sight \& Sound, 20(10): 34-40.

Magor, M and Schlesinger, P (2009), "For this relief much thanks." Taxation, film policy and the UK government', Screen, 50(3): 1-19.

Mansfield, M (2009), A Report on the British Film Industry for Shadow DCMS, available at: http://www.mansfieldwb.com/filmreportnov09.pdf

Marquis, A and Marquis S (1995), Art Lessons: Meditations On The Creative Life, NY: Basic Books. Middleton, P, (Chair) (1996), Report of the advisory committee on film finance, London, DNH.

Mulgan, G and Paterson, P (Eds) (1993) Hollywood of Europe? London: BFI

Murphy, R (2009), The British Cinema Book ( $3^{\text {rd }}$ Ed), London: BFI.

Nowell-Smith, G and Dupin, C (2012), The British Film Institute, the government and film culture, 1933-2000, Manchester: Manchester University Press.

O'Regan, T and Goldsmith, B (2006). 'Making cultural policy - meeting cultural objectives in a 
digital environment', Television \& New Media, 7(1): 68-91.

Parker, A (2002), Building a sustainable UK Film Industry, Presentation to the UK film industry, 5 November 2002.

Perkins, S (2012), 'Film in the UK, 2001-10: A Statistical Overview', Journal of British Cinema and Television, 9: 310-332

Pratten, S and Deakin, S (1999), 'Competitiveness policy and economic organisation: The case of the British film industry', ESCR Centre for Business Research, Working Paper No 127, Cambridge, University of Cambridge.

Puttnam, D (2010), 'Directors' cut: the end of UKFC' New Statesman, 14 Oct 2010.

Street, S (2009), British National Cinema 2, London: Routledge.

Street, S (2012), Digital Britain and the Spectre/Spectacle of New Technologies, Journal of British Cinema and Television, 9: 377-399.

UKFC (2004), Our Second Three Year Plan: Funding and Policy Priorities 2004-2007, London: UKFC.

UKFC (2007), Film in the Digital Age, London: UKFC.

UKFC (2010), Digital Innovations and Creative Excellence, London: UKFC.

Wayne, M (2006), 'Working Title Mark II', International Journal of Media and Cultural Politics, 2(1): 59-73. 